\title{
Alternative Dispute Resolution and Collective Conciliation in Nigeria: A Review of Contemporary Literature
}

\author{
Ige Adejoke Yemisi ${ }^{1}$ \\ ${ }^{1}$ Department of Employment Relations and Human Resource Management, Faculty of Business Administration, \\ University of Lagos, Akoka, Yaba, Lagos, Nigeria \\ Correspondence: Ige Adejoke Yemisi, Department of Employment Relations and Human Resource Management, \\ Faculty of Business Administration, University of Lagos, Akoka, Yaba, Lagos, Nigeria. E-mail: \\ igeadejoke@yahoo.com
}

Received: June 14, 2017

Accepted: July 15, 2017

Online Published: July 18, 2017

doi:10.5539/ijbm.v12n8p261

URL: https://doi.org/10.5539/ijbm.v12n8p261

\begin{abstract}
The aim of this paper is to present detailed contextual understanding of employment relations, alternative dispute resolution (ADR) and collective conciliation in Nigeria. This contextual understanding is important in order to comprehend the specific evolution of ADR and collective conciliation in Nigeria, the particular configuration of employment relations institutions and the role of different stakeholders such as trade unions and employers' associations. The outcomes of this study, affirms the significance of the roles and responsibilities of the actors (employer, trade union, state and conciliator) and highlights the procedures inherent in the dispute resolution mechanism hence, revealing how the weakness of state machinery tends to frustrate the process of conciliation in practice. Additionally, this study offers a reflection of what previous studies have presented, concerning the perceptions of users about the outcomes of collective conciliation within the Nigerian context.
\end{abstract}

Keywords: Alternative dispute resolution, collective conciliation, employment relations, stakeholders, Nigeria.

\section{Introduction}

Alternative Dispute Resolution (ADR) is referred to by the International Labour Organisation (ILO) as being a substitute for the court system, namely: a set of processes that comprise of negotiation, conciliation, mediation and arbitration (ILO, 1997). This description includes a set of approaches to settling disputes which in practice vary significantly in terms of their nature and use from one institutional context to another. For instance, in some contexts ADR refers to everything from assisted settlement discussions - where disputants are encouraged to consider issues directly with each other as a first step to later legal procedures such as an arbitration system or mini-trials that look and feel very much like court processes (Brown et al., 1998).

In other contexts ADR may primarily be a means of bringing workplace justice to more people at lower cost and with greater speed than conventional government channels (Broughton and Cox, 2012; Heery and Nash, 2011; Podro and Suff, 2005). According to some scholars ADR may function as a means to overcome gaps or weaknesses in statutory dispute resolution institutions thus, supporting government agencies to meet their societal responsibilities more efficiently (Bendeman, 2007; Zack, 1997). For instance, in the United Kingdom (UK) workplace ADR seems to be increasingly used as a means of bringing employers, employees and trade unions together to resolve disputes without having to resort to litigation (Silberman et al., 1993). Conciliation is one of the most common and important forms of ADR. It is seen as a key mechanism for resolving workplace disputes as it has been estimated that conciliation is worth millions of pounds each year to the UK economy due to resolution outcomes in the form of recommendations and the number of days saved from strike actions (Dawe and Neathey, 2008; Meadows, 2007). In addition British employers, employees and trade unions agree that conciliation is a useful tool to help with the resolution of disputes (Hale et al., 2012; ACAS and Ipsos Mori, 2006; Molloy et al, 2003; Hunter, 1977). Given the above explanations on the effectiveness of ADR and collective conciliation within other contexts, this present study aims at addressing the gap in literature by presenting an account of ADR and collective conciliation within the Nigerian context.

This paper provides detailed contextual understanding of employment relations, ADR and collective conciliation in Nigeria. This contextual consideration is essential in order to comprehend the specific evolution of ADR and collective conciliation in Nigeria, the particular configuration of employment relations institutions and the role of 
different stakeholders such as trade unions and employers' associations.

This paper is divided into six sections and structured as follows: Section two considers the history and emergence of ADR in Nigeria. It offers a contextual overview of the employment relations system in Nigeria. Section three considers the significance of the roles and responsibilities of the actors (employer, trade union, state and conciliator). Section four presents a reflection on ADR mechanisms in Nigeria. It examines the nature and context of ADR, forms of ADR that are operational in Nigeria and key dispute resolution institutions, notably the National Industrial Court of Nigeria. It highlights the procedures inherent in the dispute resolution mechanism and reveals how the weakness of state machinery tends to frustrate the process of conciliation in practice. Section five examines collective conciliation as a form of ADR in Nigeria by investigating empirical studies that have been conducted on collective conciliation in Nigeria and considers the effectiveness of the process in practice. It offers a reflection of what previous studies have presented, concerning the perceptions of users about the outcomes of collective conciliation in Nigeria, and then conclude.

\section{2: History and Emergence of ADR in Nigeria}

In order to have a comprehensive account of ADR mechanisms in Nigeria, an investigation into the basic structures of employment relations (pre-colonial, colonial and post-colonial eras) is essential (Otobo, 1988; Ubeku, 1983). An understanding of the key features of employment relations in Nigeria needs to begin with the pre-colonial era when paternalism was in operation in the predominantly agricultural economy: the father was the employer and members of his immediate family were the employees (Yesufu, 1982; Lovejoy, 1974; Iwuji, 1968). With the advent of colonialism, the political and administrative activities of the British government led to the introduction of a more formal, voluntary employment relations practice derived from the Anglo-Saxon model of industrial relations (George et al., 2012; Dike, 2008). Within this framework, workers and employers are seen to be in the best position to deal with situational factors, such as conflict, that tend to arise within the workplace (Lovejoy, 1974; Florence, 1957). The state is not expected to intervene directly in dispute settlement procedure, although it is required to establish the legal framework needed for voluntary negotiations and collective bargaining (Dike, 2008; Ubeku, 1983).

Critics of this model of industrial relations argue that the colonialists imposed voluntarist employment relations practice on Nigerians based on the predominant socio-political and economic philosophy in Britain without taking due consideration of the unique culture, principles, level of civilisation and prevailing employment relations practice in Nigeria (Adebisi, 2013; George et al., 2012; Onimode, 1981; Ananaba, 1969; Kilby, 1967; Cook, 1943). The activities of early nationalist-war veterans led to labour unrest which focused on the desire for labour, economic and democratic reforms in the 1920s. This led to the replacement of the voluntarism model of employment relations by state interventionism employment relations practice in the 1940s. This practice continued after independence in 1960, and during the military administration, which ended in 1993 (George et al., 2012; Ubeku, 1983). Scholars affirm that in the $21^{\text {st }}$ century, Nigeria's employment relations system is best described as a hybrid: the system depicts a combination of voluntarism and state intervention. It demonstrates the importance of the role of the state in employment relations and the degree to which its participation impacts on the policies that guide industrial relations practice in Nigeria (Adebisi, 2013; George et al., 2012; Ubeku, 1983).

\section{Roles and Responsibilities of the Actors}

The tripartite actors that operate within the employment relations context in Nigeria are: trade unions, employers' association and the Nigerian state-represented by the Ministry of Labour. According to the Trade Union Act (1990) 'a trade union is defined as any combination of workers or employers, whether temporary or permanent, the purpose of which is to regulate the terms and conditions of employment of workers'. Given this description, there are two major umbrella trade unions that represent the interest of employees (junior and senior) in Nigeria. The Nigeria Labour Congress (NLC) was founded in 1978, following the merger of four different organisations namely: Nigeria Trade Union Congress (NTUC), Labour Unity Front (LUF), United Labour Congress (ULC) and Nigeria Workers Council (NWC). NLC has twenty-nine affiliated unions and a total of four million members.

The second umbrella union is the Trade Union Congress of Nigeria (TUCN). TUCN was officially registered in 2005 but prior to this time, it was known in the 1980's as Federation of Senior Staff Associations of Nigeria (FESSAN) and in the 1970's as Senior Staff Consultative Association of Nigeria (SESCAN). TUCN has twenty-two affiliated unions and a total of 2.5 million members. A review of the aims, objectives and roles of NLC and TUCN reveals that both unions are committed to promoting and safeguarding the economic and social welfare of their members by preserving and extending their rights within a just, free and democratic society. This suggests that the aims and objectives of trade unions in Nigeria is to maintain favourable industrial relations practice that 
strengthens collective bargaining and safeguards equitable observance of collective agreements reached between the trade unions and employers; with a view to enhancing the quality of life, income and working conditions of workers. The role of trade unions in Nigeria can therefore be summarised as providing supporting data and documents during negotiations, influencing labour legislation and improving bargaining abilities of affiliate members. In addition, trade unions intervene in industrial disputes by ensuring that the outcomes of dispute resolution takes into account the need to protect the employees and support union affiliates (George et al., 2012; Trade Union Act, 1990; Ubeku, 1983).

The employers' association body registered and recognised by trade unions and the Ministry of Labour is the Nigeria Employers' Consultative Association (NECA). NECA was established in 1957 and its aim is to provide favourable conditions for government to deliberate and consider socio-economic and labour related policies and issues with private sector employers. Although NECA can be described as a trade union given the descriptions presented in the Trade Union Act (1990) NECA affirms that even though it is the umbrella organization of employers in the Organised Private Sector of Nigeria it is not a trade union. Consequently, NECA does not relate with trade union organisations during collective bargaining or dispute resolution however; NECA is recognised as employers' representatives during the review of minimum wage, labour laws and the practice of industrial relations in Nigeria. NECA provides advisory and consultative services to their members with a view to promoting harmonious business environment that brings about increase productivity and efficiency. This explanation indicates that while there is an association that represents the interest of employees during collective bargaining and dispute resolution in Nigeria, there is no employers' association that carries out this function and as such, this obligation is conducted by management representatives within individual organisations. This indicates that the responsibility of negotiating with trade unions during collective bargaining and dispute situation has been ascribed as part of the responsibilities of the Human Resource Manager (HRM) on behalf of the organisation's management (Fajana, 2007; Otobo, 2000; Adewumi, 1997; Otobo and Omole, 1987).

The role of the Nigerian state in employment relations is based on the premise that employers and trade unions cannot be left with the responsibility of regulating the workplace (Badejo, 2011; Otobo, 1983). Some scholars claim that direct state intervention in labour related matters is aimed at promoting democracy and safeguarding economic, political, social, historical and international responsibilities (Badejo, 2011; Otobo, 1988). Contenders of this viewpoint maintain that state regulations in labour related issues are often manipulated in the growth of employment, wages and salaries, collective bargaining, industrial conflict and trade union administration (Otobo, 2000; Fashoyin, 1991; Otobo and Omole, 1987). Others suggest that the Nigerian state tends to protect sectorial and private interest. According to these studies, this attitude of the state is usually opposed with resistance among trade unions in the form of strike action (Badejo, 2011; Damachi and Fashoyin, 1986; Trevoedjre, 1969). These studies assert that a nation's economic growth cannot be realized without the activities of profit-making private companies and whenever trade unions seek improvement in their terms and conditions of employment they are seen as a threat by the state (Geary, 1985; Otobo, 1983). This is because the state wants to minimize disruption to production, eliminate threats to investment and ensure a buoyant economy, especially when members of Nigeria's ruling parties and elite system are the investors that own the private companies operating in Nigeria. Trade unions are perceived by the Nigerian state as potential alternatives and as such, the state develops strategies to deal with the pressured threat by trade unions (Badejo, 2011; Otobo, 2000; Otobo and Omole, 1987).

For some, the intervention of the state in employment relations in Nigeria regulates the economy, stimulates technology and overcomes unnecessary bottlenecks that may arise especially during dispute resolution (Otobo, 2000; Damachi and Fashoyin, 1986). Critics on the other hand contend that the Nigerian state is biased and its neutrality is in doubt. According to these studies, the state is dedicated to the promotion of private property. This becomes evident in the manner in which the state has historically given concession to employers through reduced tax, custom duties and minimum wages to the detriment of the workers and trade unions (Badejo, 2011; Kilby and Kilby, 1969). As a major employer of labour, the Nigerian state is expected to set the pace for private employers by establishing a standard for good employment relations practice. However, this does not seem to be the situation, as studies emphasise that the state simply creates more misperception and disenchantment with the kind of policies adopted in the public sector (Otobo, 1992; Keller, 1991; Fashoyin, 1991). Others maintain that the outcomes of the state's regulatory functions are suspect because they have the tendency to be manipulable, pliable and contestable especially at the implementation stage. Other scholars contest the effectiveness and timing in the settlement of employment relations disputes (George et al., 2012; Badejo, 2011). According to these studies, the bureaucratic and deliberately sluggish consideration and administration of justice tends to undermine and weaken the process of resolution (Otobo, 1992; Fashoyin, 1991). Others maintain that the 
overbearing and domineering influence of the state on the decisions of the court and other settlement institutions not only undermines their integrity, but also brings about contempt for and disregard of these institutions (Adebisi, 2013; Otobo, 2000).

Trade unions have made it their responsibility to address deep-rooted inequalities that may arise within the Nigerian state (Okolie, 2010; Fajana, 2007; Otobo, 2000; Adewumi, 1997). Some have argued that given the prejudiced disposition of the Nigerian state during its intervention in employment related issues, the main weapon that trade unions can use to exercise their relational power during negotiation is strike action (Kolagbodi, 1995; Fashoyin, 1987; Ubeku, 1983). The state has whittled down the effect of this with the introduction of inhibiting legislation such as the Trade Disputes Act (1976) that constrains the activities of trade unions, particularly their right to strike (Badejo, 2011; Fashoyin, 1987; Ozaki, 1987). Furthermore, the state denies workers in the public sector the right to strike by categorising their operation as an essential service and thus subjecting them to compulsory arbitration in lieu of exercising their right to strike (Okene, 2010; Okolie, 2010). Even in the private sector the right to strike seems to be constrained because of the procedures laid down. According to these studies, in instances when trade unions are dissatisfied with the award of the industrial court, they are advised to begin another round of the settlement process instead of embarking on a strike (Adefolaju, 2013; Badejo, 2011; Jacobs, 1993). These scholar argue that given the above situation trade unions perceive their re-run of the process as frustrating and tantamount to a waste of time and effort, given the cumbersome and burdensome nature of the process (Okene, 2010; Adewumi, 1997). The most noticeable impact of state legislation on trade union activities in Nigeria is in relation to membership. Previous scholars argue that trade union membership has continued to decline, with fewer than $11 \%$ out of 29 million wage earners organised into trade unions (Otobo, 2007; Fajana, 2007). According to these studies, the number has continued to decline in both the public and private sector. Others assert that industrial relations practices in Nigeria are becoming inadequate because of the inability of trade unions to prevent employers' infringement of human rights and poor treatment of employees (Adefolaju, 2013; Adebisi, 2013; Okene, 2010; Adewumi, 1997).

\section{Nature of ADR Mechanisms in Nigeria}

Having set out the key features of employment relations practice and how the role of the state and trade unions has evolved within the Nigerian state, a closer consideration of ADR mechanisms in Nigeria is crucial. They are comprised of mediation, arbitration and conciliation. The term ADR has been defined by several scholars within the Nigerian context. For instance, Aina (1998) describes ADR as mechanisms used in settling differences of opinion fast and without altering the relationships that exist between the parties. Closely linked to this viewpoint are scholars who describe ADR as the procedures used to resolve disputes as alternatives to the traditional resolution mechanism of the court (Fagbemi, 2014; Asonibare, 2011). In the Nigerian context ADR is seen as a quick, relatively non-adversarial and objective process for resolving disputes when compared to legal proceedings. In addition, while resolving a dispute using ADR in Nigeria emphasis is placed on sustaining the mutual relationships that exists between the disputing parties (Fagbemi, 2014; Asonibare, 2011; Orojo and Ajomo, 1999).

The Trade Disputes Act (1976) in Nigeria introduced formal processes for managing disputes. Trade dispute as described by some scholars is any disagreement that exist between employers or among employers and employees connected with employment, non-employment and physical conditions of work (Akume and Abdullahi, 2013; Fajana, 2006; Aturu, 2005). The 1976 Trade Disputes Act was repealed in 2004 and under the terms of the 2004 Trade Disputes Act, the first stage in the process of resolution of trade dispute is for the parties to explore internal procedures made available within the organization. If and when this initial attempt fails the next alternative is when the parties jointly agree on the appointment of a neutral and impartial third party known as the mediator. Mediators are labour officers that work and are trained in the Ministry of Labour however; their appointment to preside over mediation meeting is dependent on the mutual agreement of both parties. Given that mediators are trained officers at the Ministry of Labour and based on their level of training, knowledge and understanding of the process of mediation, the responsibility of the mediator is to explore with the disputing parties the possibility of resolving the issues in dispute by making suggestions and recommendations on the way forward, with a view to attaining amicable settlement of the dispute. In Nigeria, mediation is the first ADR method that disputing parties are required to explore before completing the Trade Dispute 3 (TD/3) form which allows them to officially declare a trade dispute. The process of mediation is considered before conciliation and arbitration in Nigeria because; it gives the disputing parties the opportunity to re-consider the issues in their dispute for the first time with the assistance of an independent third party in the person of the mediator. Also mediation can be said to be less formal compared to conciliation because once the parties complete the TD/3 form, the dispute is said to have commenced the formal process towards resolution and the final stage of this 
process is the National Industrial Court (Trade Disputes Act, 2004; Otobo, 1987).

According to the TD Act (2004) disputing parties are expected to embark on the process of mediation within seven days of the date on which the dispute arose. If settlement is not achieved by the mediator within another seven days of his or her appointment, the dispute is reported in writing by the mediator. The disputing parties are also required to complete the TD/3 form which is forwarded with the report of the mediator to the Minister of Labour and Productivity. The completion of the TD/3 form by the disputing parties formally indicate the failure of settlement at mediation, existence of trade dispute and willingness of the parties to proceed to the next stage of resolution which is conciliation (Trade Disputes Act, 2004; Ojielo, 2001). However, TD Act (2004) allows the Minister of Labour to apprehend a dispute even before it is reported by the parties or the mediator. In situations like this the Minister informs the disputing parties in writing of his apprehension of their case and makes suggestions or propositions on the steps that could be taken by the parties to resolve the dispute (Odoziobodo, 2015; Kale, 2011; Trade Disputes Act, 2004; Ojielo, 2001).

Conciliation is the next stage of the dispute resolution process. On receiving the 'failure of settlement' report from the mediator and the completed TD/3 form from the disputing parties, the Minister is expected to appoint a conciliator. In most instances the group of conciliators appointed by the Minister of Labour for this purpose are senior labour officers, chief labour officers and other high ranking officers that work and are trained at the Ministry of Labour and in particular, the Trade Union Services and Industrial Relations (TUSIR) Department (Conciliation Rules, 2004).The responsibility of the conciliator at this stage in the dispute settlement process is to investigate and obtain full account into the reasons and conditions that surround the dispute. In the course of discussions with the parties, the conciliator's expectation is assist the parties identify the key issues in dispute during negotiations and to facilitate resolution (Njoku and Nwosu, 2007; Ezejiofor, 1997). In circumstances where settlement is not reached within seven days of the appointment of the conciliator or if, after attempting to negotiate with the parties, the conciliator is satisfied that settlement cannot be attained, the conciliator can report in writing to the Minister of Labour the failure to resolve the dispute at conciliation.

Upon receiving the report on the failure to resolve the dispute at conciliation, the Minister is expected to refer the dispute for settlement at the Industrial Arbitration Panel (IAP) within fourteen days; hence, the process of conciliation precedes IAP in Nigeria (Njoku and Nwosu, 2007; Conciliation Rules, 2004; Ezejiofor, 1997). It is imperative to mention that the failure of the parties to resolve the dispute at conciliation indicates their readiness to hand over their right to decide the outcome of resolution to the arbitrator. It also illustrates the preparedness of the parties to accept the outcomes of arbitration and its implication on trade unions and management relationship. The IAP consists of a chairman, a vice chairman and other members all of whose appointment in the first instance is for a four year period and renewable only for another four years. Although members of the IAP and assessors are not employees at the Ministry of Labour, the TD Act (2004) empowers the Minister of Labour to pay members of the IAP and assessors their remuneration based on the approval of the Minister of Finance.

In Nigeria, there are three types of arbitration hearing namely: arbitration tribunal, sole arbitration and single arbitration. Arbitration tribunals consist of the chairman and vice chairman who are usually appointed by the Minister of Labour while other members of the tribunal are nominated by the disputing parties: two of the appointed members are nominated by the organisation hence, representing the interest of the employer. Another two nominees are appointed by the employees and their trade unions. In addition, the employer and trade unions are expected to nominate one arbitrator each from among the members of the IAP to be involved in the arbitration process.

The Arbitration and Conciliation Act (1990) makes provision for sole arbitration process and the arbitrator that presides over the hearing is selected from among the members of IAP by the chairman. A single arbitrator is usually appointed by the chairman of IAP but assisted by one or more assessors. Within the context of arbitration in Nigeria, assessors are appointed by the chairman of IAP. The panel of assessors consist of persons recommended and endorsed by the Minister of Labour for the purpose of arbitration and their aim is to represent the interest of employers and trade unions during arbitration hearing. When the dispute is presented for arbitration the IAP is expected to consider the case and make its award within twenty-one days of its formation. Prior to the arbitration hearing the parties are expected to submit their statement and all the documents/evidence that they consider relevant to the hearing and every statement, document and information supplied to the arbitrator or arbitration tribunal must be communicated by both parties to each other. The IAP gives both parties sufficient advance notice of the hearing date, venue and time. The parties are also given adequate time to prepare for any meeting of the arbitrator or arbitration tribunal for the purpose of inspection of documents, goods or other properties. The IAP informs the disputing parties in advance to the hearing that if they fail to appear at arbitration or fail to produce documentary evidence at the arbitration hearing the IAP has the right to continue 
with the proceedings and make an award on the dispute. During the arbitration hearing the arbitrator is required to accord both parties equal treatment and full opportunity to present their case so as to ensure fair and impartial hearing. The responsibility of the arbitrator is to determine the relevance, pertinence and weight of any evidence place before it by the disputing parties; and at the end of the hearing make an award. The award of IAP is not communicated by the panel to the parties instead, it is sent to the Minister to consider its desirability before presenting the award to the disputing parties.

If the parties are unhappy with the award at the end of arbitration they can within three months from the date of the award refer the case to the highest court for trade dispute settlement in Nigeria: the National Industrial Court of Nigeria (NICN) (Onyearu, 2015, Arbitration and Conciliation Act, 1990). This explanation indicates that the disputing parties can progress with resolution by making an appeal on the award of their case at the industrial court hence; arbitration comes before industrial court in the dispute resolution process in Nigeria. The NICN consist of the President whose appointment is based on the recommendation of the National Judicial Council (NJC) subject to confirmation by the upper legislative arm (Senate). Other members of the NICN are Judges appointed by the President of the court on the recommendation of the NJC. Consequently, selection into the NICN is dependent on the legal qualification and practice by the candidates for not less than ten years in Nigeria. Additionally, candidates for the position of President and Judge in the NICN are required to have considerable knowledge and experience of the law and practice of industrial relations and employment conditions in Nigeria.

NICN exercise jurisdiction in matters connected with labour and employment relations, trade unions and workplace related issues such as conditions of service, health, safety and welfare of employees. The NICN also has the authority to preside over matters relating to Factories Act, Trade Disputes Act, Trade Unions Act, Workmen's Compensations Act or any other Act or Law involving to labour, employment, industrial relations, workplace or any other enactment replacing the Acts or Laws. Furthermore, the NICN has the authority to apply its influence on matters connected with the grant of any order restraining any person or body from taking part in any strike, lockout or any industrial action, or any conduct in furtherance of a strike, lock-out or any industrial action. The NICN's prerogative also covers disputes that are connected with unfair labour practice or international best practices in labour, employment and industrial relation matters, interpretation of international labour standard connected with child labour, child abuse and human trafficking (Constitution of the Federal Republic of Nigeria-Third Alteration Act, 2010; NIC Act, 2006).

On receiving a case at the NICN, the Court is empowered to confirm a judgment, an award or order made by the Court, tribunal or body mentioned in the matter before it; to vary a judgment, an award or order made by the Court, tribunal or body mentioned therein; to set aside a judgment, an award or order made by the Court, tribunal or body mentioned therein; to order a rehearing and determination on such terms as it thinks just; to order judgment to be entered for any party; to make a final order or other order on such terms as it may think fit to ensure the determination on the merits of the matter in dispute between the parties. The court may also decide to make a final order on the terms of the case as it may deem fit. The aim of the NICN at this stage in the dispute resolution process is to ensure final and absolute settlement that is based on the evidence presented by the parties and on the merits of the case (NIC Act, 2006). The decision awarded by the NICN is usually binding on the parties because the NICN is recognised as a superior court of record in Nigeria. This suggests that once a case is decided by the NICN it is no longer subject to appeal or to the supervisory jurisdiction of any other court in Nigeria. The key point is that the NICN has ultimately exclusive authority over labour, trade union and industrial relations matters in Nigeria (Worugi et al., 2007; NIC Act, 2006; Kanyip, 2003).

The process as set out above involves a relatively rapid progression of disputes towards resolution with each stage taking a matter of days and weeks, rather than months. However, critics of this ADR method in Nigeria argue that within the context of the TD Act (2004) the Minister of Labour and Productivity has absolute power to refer unresolved disputes as the case may be. According to these studies the position of the Minister is political and as such, his appointment could be said to be a reflection of the standpoint of the political party in power (Onyearu, 2015; Omobamidele and Adekunbi, 2013). This suggests that based on the power invested in the Minister of Labour there could be a tendency for the process of trade dispute resolution to be influenced or manipulated. It could also put the independence, impartiality and objectivity of the process in doubt, in the view of employers and trade unions (Okaka and Eriaguna, 2011; Aturu, 2005). Looking at the empirical evidence on the extent of mediation, conciliation and arbitration reveals that in 2015 a total of 212 disputes were reported for mediation but only 3 of these were resolved. Statistical evidence shows that between the years 2010-2014 a total of 1,182 disputes were reported at mediation and only $80(6.7 \%)$ of these reported cases were settled (Onyearu, 2015; Omobamidele and Adekunbi, 2013).

Turning to arbitration, many have argued that it is little more than an abridged form of hearing. The parties' 
decision to choose arbitration is seen by many to indicate their willingness to relinquish their decision-making rights to the arbitrator and also to accept in good faith, the outcome of arbitration (Essien, 2014; Orojo and Ajomo, 1999). The arbitration rules reveal that arbitrator's decision on a dispute can either be binding or non-binding on the parties, as the case may be. If binding, the arbitrator's award is final and the party that succeeds may decide to implement the outcome of the award against the other party. However, if the award is not binding on the parties the decision would be viewed by the parties as a form of recommendation that can be used to settle the dispute (Arbitration Rules 2004).

Critics of this view affirm that because of the extensive influence and control given to the Minister of Labour over the IAP in the TD Act, the IAP seems to be a unit under the Ministry of Labour. This suggests that there is no opportunity for the IAP to demonstrate its independence and impartiality to the disputing parties (Essien, 2014; TD Act, 2004; Arbitration and Conciliation Act, 2004; Arbitration Rules 2004; Orojo and Ajomo, 1999). Empirically generated findings on arbitration in Nigeria reveal that in 2015 a total of 105 disputes were reported and only 9 of such disputes were resolved. Statistical evidence shows that between the years 2010-2014 a total of 353 disputes were reported at arbitration and 65 (18\%) of these were settled (Essien, 2014; Orojo and Ajomo, 1999).

Conciliation has been described among scholars in Nigeria as an alternative way of settling disputes (Onyearu, 2015; Orji, 2012). According to these studies, the process of conciliation involves the conciliator assuaging, pacifying and calming the disputing parties during negotiations with the aim of achieving resolution (Njoku and Nwosu, 2007; Black et al., 1999). In Nigeria, studies have drawn similarities between conciliation and mediation because both processes require the intervention of neutral third parties (Aturu, 2005; Orojo and Ajomo, 1999). Closely linked to this view are studies that affirm that in mediation and conciliation the third parties do not have the power to impose binding opinions on the parties and as such, the outcome of the dispute is based on the agreement of both parties (Orji, 2012; Anekwe, 2010; Njoku and Nwosu, 2007; Black et al., 1999). However, there are key differences in the processes associated with conciliation and mediation. Conciliators bring the parties together to find a compromise solution to their dispute while in mediation the mediator draws up the terms of settlement, which represents a fair compromise of the dispute based on available information and evidence (Orji, 2012; Anekwe, 2010; Njoku and Nwosu, 2007; Ezejiofor, 1997). Unlike arbitration, conciliators do not give a decision on the dispute; instead, the aim of conciliation is to encourage to parties to come to their own settlement of their dispute (Arbitration and Conciliation Act, 2004; Arbitration Rules 2004). In arbitration, the parties are required to present their case formally during the hearing while in conciliation the conciliator relates with the parties informally. The outcome of conciliation depends on the will of the parties, while in arbitration the verdict is given by the arbitrator who makes the award (Orji, 2012; Arbitration and Conciliation Act, 2004; Arbitration Rules 2004; Orojo and Ajomo, 1999).

Empirically generated findings on conciliation in Nigeria reveal that in 2015 a total of 296 disputes were reported, of which 191 were resolved. Statistical evidence shows that between the years 2010-2014 a total of 1,547 disputes were reported at conciliation and 873 of these cases (56.4\%) were settled. Compared to arbitration and mediation there is a much higher success rate with conciliation and some have suggested that the process is effective in assisting the parties to identify their mutual interest, make a compromise and achieve resolution (Ministry of Labour, 2016).

An important role in dispute resolution is also played by the National Industrial Court of Nigeria (NIC Act, 2006; TD Act 2004). This is a judicial institution established by the TD Act (1976) but which only became operational in 1978. The aim of the court on its formation was to promote industrial harmony through timely but impartial resolution of disputes arising from industrial relations. In accordance with the above objective the NICN is empowered to confirm a judgment, an award or an order made by the IAP (Onyearu, 2015; Worugi, et al., 2007; NIC Act, 2006). In addition it can decide to vary a judgment, set aside an award, order a re-hearing and determination of a case, make a final order and ensure the determination of the dispute depending on the merits of the issues in dispute. While carrying out its responsibilities the NICN is expected to maintain integrity, reliability, transparency and fairness (NIC Act, 2006; Kanyip, 2003; Constitution FRN, 1999). In addition, the court is required to provide an enabling environment for industrial development and economic growth. The above explanation suggests that while carrying out its adjudicatory functions the NICN is obliged to enable a supportive environment that would encourage the cordial settlement of disputes and stimulate friendly labour and industrial relationships (NIC Act, 2006; Orojo and Ajomo, 1999).

In 1999 the Nigerian Constitution established NICN as a superior court of record in Nigeria (Constitution FRN, 1999). This indicates that NICN can now exercise exclusive jurisdiction in civil cases and matters that relate to labour, trade unions, industrial relations and problems that arise from the workplace such as conditions of service, 
health and safety, welfare of labour and other related matters. In 2006 the National Industrial Court Act strengthened the roles and responsibilities of the NICN further (NIC Act, 2006; TD Act 2004; Kanyip, 2003; Constitution FRN, 1999). It confirmed the role of the NICN in assisting with the resolution of disagreements concerning work environment, conditions and terms of work, and workplace-related Acts such as the Factories Act, Trade Unions Act, Labour Act, Workmen's Compensation Act and Trade Disputes Act. Furthermore the NICN under the 2006 Act continues to have the ability to resolve disputes that are connected with strikes, lock-outs, industrial action, trade unionism and employer's associations (Onyearu, 2015; Worugi, et al., 2007; Kanyip, 2003; Orojo and Ajomo, 1999). Beyond this, the disputes where the NICN can assist in determination include those relating to the minimum wage, unfair labour practices, discrimination and sexual harassment at work, application or interpretation of international labour standards, child labour and child abuse, human trafficking, and the interpretation and application of collective agreements (NIC Act, 2006; TD Act 2004; Constitution FRN, 1999).

\section{5: Collective Conciliation as a Form of ADR in Nigeria}

As outlined in section two, the process of conciliation in Nigeria can be said to have commenced with the appointment of the conciliator (Arbitration and Conciliation Act, 2004). The conciliator's initial action is to contact the parties in dispute in writing. In this letter the conciliator informs the parties of his or her appointment and role, which is to assist with the resolution of the dispute. This is followed by an initial stage of conciliation in which the conciliator reminds the parties to submit a written statement (which both disputing parties can see) recounting the nature of the disagreement and their key concerns, before the confirmed date for conciliation. Furthermore, the conciliator informs the parties that they are expected to send a copy of the statement to the other party as well, for them to read through and prepare their defence (Conciliation Rule, 2004). At the hearing, the process of conciliation is very similar to that in other countries. The conciliator assures the parties of the confidentiality of the process and its outcomes and notifies the parties of the need to negotiate in good faith by providing evidence and making submissions when necessary (Arbitration and Conciliation Act, 2004; Conciliation Rules, 2004). Once the introduction has been made by the conciliator, the aggrieved party is asked to present their case and the other party is then requested to defend their position based on the presentation made by the aggrieved party. In the course of the hearing the conciliator may decide to meet the parties separately. The intention of the conciliator during this process is to deliberate with the parties on the issues in dispute in more detail and also to identify the underlying factors that influence the positions of the parties (Arbitration and Conciliation Act, 2004; Conciliation Rule, 2004).

If the conciliator identifies elements of settlement that can be acceptable to both parties the conciliator can decide to draft the terms of agreement and present these to the parties for comment. After receiving their comments, the conciliator may decide to reformulate the terms in light of the observations presented by the parties. If at the end of conciliation the parties reach an agreement on the settlement of their dispute, a written settlement agreement is drawn up by the conciliator at the request of the parties, and signed and dated by them. In instances where the dispute is not settled by conciliation, the conciliator drafts a disagreement letter stating the issues and dispute and the steps taken at the conciliation stage. The case is then referred to the Minister of Labour who can assess it and decide whether to refer it to the IAP (Arbitration and Conciliation Act, 2004; Conciliation Rule, 2004).

Research in the Nigerian context has highlighted the important role of conciliators in assisting disputing parties to reach an amicable resolution by using the principles of objectivity, fairness and justice and by taking into consideration the rights and obligations of the parties, usage of trade concerns, circumstances surrounding the dispute and previous business practices between the parties (Arbitration and Conciliation Act, 2004; Ojielo, 2001). Studies have also examined the circumstances of collective conciliation. Collective bargaining and industrial conflict are two key factors associated with recourse to conciliation (Phillips, 2013; Anyim et al., 2012). Conflicts during collective bargaining are linked to salary and wages, leave and salary allowances, hours of work, retrenchment and other matters connected to the terms and conditions of employment (Ekwoaba et al., 2015; Ibietan, 2013; Anyim et al., 2012). Studies have argued that public sector organisations in Nigeria are more likely to see trade union and management related disputes due to a greater presence of trade unions, more rigid bureaucratic structures, and mechanistic management philosophies and attitudes. However, disputes and recourse to conciliation do also occur in private sector Nigerian organisations (Phillips, 2013; Ofoele, 1986; Akpala, 1982).

Strikes are another factor associated with recourse to collective conciliation (Uzoh, 2016; Ifedi, 1994). Research studies in the Nigerian context have considered the factors associated with conciliation outcomes. According to these studies, this mind-set of the actors has the tendency to impact on their perception and determine their willingness to resolve the issues in dispute and promote amicable resolution (Odoziobodo, 2015; Akinwale, 
2011). The opinion of one party towards the other tends to influence their actions during negotiations. In the Nigerian context, studies have also highlighted that procedures inherent in the dispute resolution mechanisms, and the relative weakness of state machinery tend to frustrate the process of dispute resolution (Oghenekaro, 2013; Akume and Abdullahi, 2013; Olawale, 2011). The key point to take into consideration is that the perception of the actors regarding the attitude and behaviour of each other, as well as the process and outcomes of conciliation, is important because it has the tendency to influence their opinion and determine their willingness to conform to the outcomes of negotiations (Uzoh, 2016; Odoziobodo, 2015; Akume and Abdullahi, 2013). However, no previous empirical study has considered the standpoint and perception of the actors regarding their actions and behaviours during collective conciliation in Nigeria.

\section{Conclusion}

In conclusion, this paper reveals that prior to the colonial era paternalist employment relations practice was in operation in Nigeria, but during colonialism voluntary employment relations practice was introduced and later replaced with state interventionism. In the $21^{\text {st }}$ century, Nigeria's employment relations system can be described as a hybrid one, a combination of voluntarism and state intervention in its approach. The role of the state is based on the premise that employers and trade unions cannot be left with the responsibility of regulating the workplace. The state has been accused by scholars of protecting sectorial and private interest because members of the Nigerian ruling parties and elite system are the investors that own the private companies operating in Nigeria. The impartiality and neutrality of the state has been contested and the outcomes of the state's regulatory functions are suspect because they have the tendency to be manipulable, pliable and contestable particularly, at the implementation stage. The main weapon commonly used by trade unions to exercise their relational power is strike action. The state has been indicted for whittling down the effect of the strike weapon by its introduction of inhibiting legislation that constrains the activities of trade unions. The impact of state legislation on trade union membership is evident, as this has continued to decline, with fewer than $11 \%$ of 29 million wage earners organised into trade unions.

The process of conciliation in Nigeria is different from other countries like UK because in Nigeria, the disputing parties are required to explore mediation before moving on to conciliation but in the UK conciliation is used first by the parties. Conciliation can be said to have commenced with the appointment of the conciliator by the Minister of Labour in Nigeria; this again is different from the UK when the conciliator is appointed by the Advisory Conciliation and Arbitration Service (ACAS). Nevertheless, one similarity between the method of conciliation in Nigeria and the UK is that if at the end of conciliation the parties reach an agreement on settlement, a written settlement agreement is drawn up by the conciliator, and signed and dated by the parties. In instances where the dispute is not settled the conciliator drafts a disagreement and refers the case to the Minister of Labour who then decides on the next step. Empirical studies on conciliation in Nigeria confirm that the roles and responsibilities of the actors highlight the procedures inherent in the dispute resolution mechanism in Nigeria. They demonstrate the extent to which the weakness of state machinery frustrates the process of conciliation in practice. As at the time of writing this article, it has become obvious that no previous research in Nigeria has considered the perception of the actors regarding the effectiveness of collective conciliation, nor has any previous study considered the opinion of the actors regarding their behaviours, perceptions and actions during collective conciliation. Hence, this study suggests the need for future studies to address this crevice in empirical literature within the Nigerian context.

\section{References}

ACAS and Ipsos Mori. (2006). Service user's perceptions of Acas' conciliation in Employment Tribunal Cases (2005): Acas Research and Evaluation Section and Ipsos MORI. Ref: 01/06.

Adebisi, M. A. (2013). History and Development of Industrial Relations in Nigeria: Hybridity of Western Models Versus Military Interventionism Culture. Mediterranean Journal of Social Sciences, 4(14), 87.

Adefolaju, T. (2013). Trade Unions in Nigeria and the Challenge of Internal Democracy. Mediterranean Journal of Social Sciences, 4(6), 97.

Adewumi, F. (1997). Responsiveness in Trade Unionism: The Challenge of the 21st century. Trade Unionism in Nigeria: Challenges of the 21st Century (pp. 181-200). Lagos: Friedrich Ebert Foundation.

Aina, K. (1998). Alternative Dispute Resolution. Nigeria Law and Practice Journal, 2(1).

Akinwale, A. A. (2011). Labour reform and industrial conflicts mismanagement in Nigeria. In a paper prepared for presentation at the sixth IIRA African Regional Congress of Industrial Relations: Emerging Trends in Employment Relations in Africa: National and International Perspectives. 
Akpala, A. (1982). Industrial Relations Model for Developing Countries, the Nigerian System. Fourth Dimension Publishers.

Akume, A. T., \& Abdullahi, Y. M. (2013). Challenges and Prospects of Effective Industrial Conflict Resolution in Nigeria. Journal of Social Sciences, 36(2).

Ananaba, W. (1969). The trade union movement in Nigeria. Benin City. Ethiope Publishing Corporation.

Anekwe, J. (2010). Management of Industrial Conflicts in Nigeria Tertiary Institutions (A Study of Federal Polytechnic Oko 2004-2012 (Doctoral dissertation).

Anyim, C. F., Chidi, O. C., \& Ogunyomi, O. P. (2012). Trade disputes and settlement mechanisms in Nigeria: A critical analysis. Interdisciplinary Journal of Research in Business, 2(2), 1-8.

Arbitration and Conciliation Act (1990). Cap. 19 Laws of the Federation of Nigeria.

Arbitration Rules. (2004). Schedule 3 of the Nigerian Arbitration and Conciliation Act. Cap 19. Laws of the Federation of Nigeria. Cap 18 Laws of the Federation of Nigeria.

Asonibare, A. S. A. (2011). Comparative Critical Overview of Negotiation. Conciliation Mediation and Arbitration, 2.

Aturu, B. (2005). Nigerian Labour Laws: Principles, Cases, Commentaries and Materials. Lagos: Frankad Publishers.

Badejo, A. E. (2011). A critique of the role of the State in industrial relations in Nigeria.

Bendeman, H. (2007). Alternative Dispute Resolution (ADR) in the Workplace-The South African Experience. African Journal on Conflict Resolution, 7(1), 137-161.

Black, H. C., Garner, B. A., \& McDaniel, B. R. (1999). Black's law dictionary. St. Paul, Minn: West Pub Group.

Broughton, A. and Cox, A. 2012. Public sector employers' attitudes to use of Acas collective conciliation; Acas Research Publications.

Brown, S, Cervenak, C. and Fairman, D 1998. Alternative Dispute Resolution Practitioners Guide. Office of Democracy and Governance, Bureau for Democracy, Conflict, and Humanitarian Assistance, US Agency for International Development.

Conciliation Rules. (2004). Schedule 3 of the Nigerian Arbitration and Conciliation Act. Cap 19. Laws of the Federation of Nigeria. Cap 18 Laws of the Federation of Nigeria.

Constitution of the Federal Republic of Nigeria. (2010). (Third alteration) Act.

Cook, A.N. (1965). British enterprise in Nigeria. New York. Barnes and Noble.

Damachi, U. G., \& Fashoyin, T. (1986). Contemporary Problems in Nigerian Industrial Relations. Lagos. Nigeria. Development Press.

Dawe, A., \& Neathey, F. (2008). Acas conciliation in collective employment disputes; Acas research publications.

Dike, K. O. (2008). Trade and politics in the Niger Delta. 1830-1885. New York. ACLS history e-book project.

Ekwoaba, J. O., Ideh, D. A., \& Ojikutu, K. R. (2015). Collective bargaining: an evaluation of conflict management strategies in the University of Lagos, Nigeria. Journal of Emerging Trends in Economics and Management Sciences (JETEMS), 6(7), 220-227.

Essien, K.B. (2014). Re-Shaping Institutions for Industrial Dispute Settlement in Nigeria-Perspectives on the Status of the Industrial Arbitration Panel. International Journal of Research, 1(6).

Ezejiofor, G. (1997). The Law of Arbitration in Nigeria. Lagos. Longman.

Fagbemi, S. A. (2014). Overview of the Institutional Mechanisms for the Settlement of Labour Dispute in Nigeria, An. US-China L. Rev., 11.

Fajana, S. (2006). Industrial Relations in Nigeria: Theory and Features (3rd ed.). Lagos: Labofin and Company,

Fajana, S. (2007). The Development of Industrial Relations in Nigeria: 1900-2006. Ch. 13. In G Wood and C Brewster (Eds.), Industrial Relations in Africa (pp. 147-161).

Fashoyin, T. (1987). Collective Bargaining in the Public Sector in Nigeria. Macmillan Nigeria Publishers.

Fashoyin, T. (1991). Recent trends in industrial relations: research and theory in developing countries. Adams, 
Roy J. Comparative Industrial Relations: contemporary research and theory. London: Harper Collins: 109-123.

Florence. (1957). Limits of Laisses-faire in Tomlonson, J. (1994) in Government and the enterprise since 1900. London. Oxford University Press.

Geary, R. (1985). Policing industrial disputes: 1893 to 1985 (937). London. Cambridge University Press.

George, O. J., Owoyemi, O., \& Onokala, U. (2012). Evolution of Employment and Industrial Relations practice: The Nigerian Experience. International Journal of Business and Social Science, 3(12).

Hale, C., Barrett, G., \& Bryce, A., Ecorys U. K. (2012). 2011/12 Acas Collective Conciliation Evaluation; Acas research publications.

Heery, E., \& Nash, D. (2011). Trade Union Officers and Collective Conciliation a Secondary Analysis, ACAS research paper Ref: 10/11 last accessed 12/12/2015.

Hunter, L. C. (1977). Economic issues in conciliation and arbitration. British Journal of Industrial Relations, 15(2), 226-245.

Ibietan, J. (2013). Collective bargaining and conflict resolution in Nigeria's public sector. Ife Psychology IA, 21(2), 220.

Ifedi. C. (1994). Strikes and the common man. Daily Times. August 5

International Labour Organization. (1997). Consensus Seeking Skills for Third Parties Training Package.

Iwuji, E. C. (1968). International handbook of industrial relations contemporary Developments and Research.

Jacobs, A. J. M. (1993). The Law of Strikes and Lock-outs in R. Blank pain and Engels, C. (Eds), Comparative Labour Law and Industrial Relations in Industrialized Market Economics (5) edn. Deventer. Kluwer: 423

Kale, K. L. (2011). An Examination of Laws and Procedures Regulating Trade Dispute in Nigeria. An Unpublished LLB Thesis, University Of Ilorin, Ilorin Nigeria.

Kanyip, B. B. (2003). Trade unions and industrial harmony: The Roe of the National Industrial Court and the Industrial Arbitration Panel. Nigerian Bar Journal. 1.

Keller, B. K. (1991). The role of the State as corporate actor in industrial relations systems. Comparative industrial relations. London, Harper Collins Academic.

Kilby, P. (1967). Industrial relations and wage determination: Failure of the Anglo-Saxon model. The Journal of Developing Areas, 1(4), 489-520.

Kilby, P., \& Kilby, S. (1969). Industrialization in an open economy: Nigeria, 1945-1966. Cambridge: Cambridge University Press.

Kolagbodi, E. (1995). Collected Speeches (1). M.E Memorial Foundation. Lagos. Malthouse Press Ltd.

Lovejoy, P. E. (1974). Interregional monetary flows in the pre-colonial trade of Nigeria. The Journal of African History, 15(4), 563-585.

Meadows, P. (2007). A review of the economic impact of employment relations services delivered by ACAS; NIESR.

Molloy, D., Legard, R., \& Lewis, J. (2003). Resolving Collective Disputes at work: User perspectives of Acas collective conciliation service.

National Industrial Court Act. (2006). Federal Republic of Nigeria. Official Gazette, 93(38).

Njoku, I. A., \& Nwosu, C. (2007). State, Industrial Relations and Conflict Management. Nigerian Journal of Labour Law and Industrial Relations, (2)

Odoziobodo, S. I. (2015). Integrity and conflict resolution in Nigeria: An analysis of trade disputes between the Federal Government of Nigeria and the academic staff union of universities, ASUU. European Scientific Journal, (11), 22.

Ofoele. (1986). Management of Industrial Disputes: Aba: Meta Printing Co. Ltd.

Oghenekaro, O. (2013). Nigerian University lecturers Commence Indefinite Strike. Channels Television.

Ojielo, M. O. (2001). Alternative Dispute Resolution. Lagos. CPA Books.

Okaka, E. O., \& Eriaguna, E. (2011). Government Agents in Nigeria's Industrial Relations System. Journal of 
Research in National Development, 9(1).

Okene, O. V. C. (2010). The challenges of Collective Bargaining in Nigeria: trade unionism at the cross-roads Nigerian Journal of Labour Law and industrial relations, 4(4).

Olawale. L. (2011). NLC call for state of Emergency in Education: Blames Greedy Ruling Class for Insensitivity. The Port Harcourt Telegraph News. December 6-13: 3-5.

Omobamidele, O., \& Adekunbi, I. (2013). Alternative dispute resolution and the criminal judicial system: a possible synergy as salve to court congestion in the Nigerian legal system. Arabian Journal of Business and Management Review (Nigerian Chapter), 1(10).

Onimode, B. (1981). Imperialism and Nigerian Development. Path to Nigerian Development, 76-93.

Onyearu, A. O. (2015). The National Industrial Court: Regulating Dispute Resolution in Labour Relations in Nigeria.

Orji, U. J. (2012). Law and Practice of Conciliation in Nigeria. Journal of African Law, 56(1).

Orojo, J. O., \& Ajomo, M. A. (1999). Law and Practice of Arbitration and Conciliation in Nigeria. Lagos. Mbeyi and Associates.

Otobo, D. (1983). Strikes in Nigeria: some considerations. The Nigerian Journal of Economic and Social Studies, 25(3), 301-318.

Otobo, D. (1987). Strikes and Lockouts in Nigeria: Some Theoretical Notes. In D. Otobo and M. Omole (Eds.), Readings in Industrial Relations in Nigeria. Lagos: Malthouse Publishing.

Otobo, D. (1988). State and industrial relations in Nigeria. Lagos. Malthouse press.

Otobo, D. (1992). Labour relations in Nigeria. Malthouse Press.

Otobo, D. (2000). Industrial relations: Theory and controversies. Lagos: Malthouse Press.

Otobo, D. (2007). Contemporary industrial relations in Nigeria. Industrial Relations in Africa. London: Palgrave Macmillan.

Otobo, D., \& Omole, M. (1987). Readings in industrial relations in Nigeria. Lagos. Malthouse Press.

Ozaki, M. (1987). Labour Relations in the Public Service -2. Labour disputes and their settlement. International Labour Review, (126), 405.

Phillips, D. D. D. (2013). A comparative analysis of trade disputes settlement in Nigerian public and private universities. Journal of Law, Policy and Globalization, (18), 61-68.

Podro, S., \& Suff, R. (2005). Making more of alternative dispute resolution. Advisory, Conciliation and Arbitration Service (ACAS).

Silberman, R. G., Murphy, S. E., \& Adams, S. P. (1993). Alternative Dispute Resolution of Employment Discrimination Claims. La. L. Rev., (54), 1533.

Trade Dispute Act. (2004). Cap T8, Laws of the Federation of Nigeria Trade Dispute Act 1976. Laws of the Federation of Nigeria.

Trevoedjre. (1969). A strategy for social progress in Africa and the ILO's contribution. International Labour Review, 99(1), 77

Ubeku, A. K. (1983). Industrial Relations in Developing Countries: The Case of Nigeria. London: Macmillan Press

Uzoh, B. C. (2016). Governments Penchant for Dishonouring Collective Agreements reached on Wages and Wage-Related Industrial Unrest in the Public Service in Nigeria. International Journal of Current Innovation Research, 2(1), 297-302.

Worugi, I. N. E., Archobong, I. A., \& Alobo, E. (2007). The NIC Act (2006) and the jurisdictional conflict in the adjudicatory settlement of labour disputes in Nigeria. An unresolved issue. Labour Law Review. 1(2): 25-33

Yesufu, T. M. (1982). The dynamics of industrial relations: The Nigerian Experience. Ibadan. University Press.

Zack, A.M. 1997. Can Alternative Dispute Resolution help resolve employment disputes? International Labour Review, 136(1). 


\section{Copyrights}

Copyright for this article is retained by the author(s), with first publication rights granted to the journal.

This is an open-access article distributed under the terms and conditions of the Creative Commons Attribution license (http://creativecommons.org/licenses/by/4.0/). 